ACTA AGROBOTANICA

Vol. 62 (2): 91-96

2009

\title{
AN ANALYSIS OF GRASS (POACEAE) POLLEN SEASONS IN LUBLIN IN 2001-2008
}

\author{
Agnieszka Dąbrowska \\ Maria Curie-Skłodowska University Botanical Garden, 20-810 Lublin, Sławinkowska 3, Poland \\ e-mail: dabrowskaa@vp.pl
}

Received: 20.07.2009

\begin{abstract}
Grass pollen allergens are a frequent cause of pollen allergy in Poland and other European countries. The research on aeroplankton conducted in Lublin since 2001 allows characterization of the course of grass pollen seasons and estimation of the effect of maximum and minimum temperatures, relative air humidity, precipitation and maximum wind velocity on the taxon's pollen concentration. The gravimetric method was used in the study. During the eight-year research period, the pollen season usually started in the first or second decade of May and, as a rule, it lasted till the end of August, and quite exceptionally, in 2002 and 2008 till mid-August. The mean length of the pollen season was 107 days. The highest grass pollen risk was observed in the $26^{\text {th }}$ and $27^{\text {th }}$ week. The highest annual counts reaching over 3600 pollen grains $\times \mathrm{cm}^{-2}$ were noted in 2008 , while in the other study years they ranged from 741 to 1909 . The date of the pollen season onset and its course were highly dependent on weather conditions, which was confirmed by the statistical analysis. The greatest significant influence on the pollen season was exerted by maximum temperature, relative air humidity and the maximum wind.
\end{abstract}

Key words: aerobiology, Poaceae, pollen season, annual counts, maximum count, meteorological conditions

\section{INTRODUCTION}

Poaceae are cosmopolitan plants which cover almost 20\% of the land area. They comprise more than 9 thousand species (T u t i n (Ed.), 1980; Clay t o n, 1993). They constitute a valuable source of food, protect the natural environment and facilitate recreational activities (M i zi anty, 1995; Fre y, 2000). In Poland, grass communities cover $4.1 \mathrm{mln}$ ha, which equals $13.4 \%$ of the country area. Their biggest agglomerations are found in the north-eastern and southern parts of the country (N i c z y p or u k, 2000; R o gal s ki, 2004).

Grasses are predominantly anemophylous plants (Weryszko-Chmielewska and Piotrow- s k a , 2006). Their flowers produce great amounts of pollen (Роа аппиа approximately 1000 pollen grains/ flower, 115 000/inflorescence, Dactylis glomerata 10 000/7 970 000, Festuca arundinacea 26 800/11 700 000 ), which is released within several minutes or a few hours, depending on the species (Piotrowska, 1999; Prieto-Baena et al. 2003; A boulaich et al. 2009). The species variety in the grass family results in pollen presence in the air for many months of the year (Rutkowski, 1998; Pi otrowska and Weryszko-Chmielewska, 2004; Puc and $\mathrm{Pu} \mathrm{c}, 2004)$. Grass pollen allergens are one of the main reasons for pollen allergy incidence in Poland and other European countries (S p i e k s m a, 1989). More than $80 \%$ of patients with plant pollen allergy suffer from that caused by grass pollen $(\mathrm{Obtułowicz}$ et al. 1990). The strongest allergens are those of Phleum, Dactylis, Lolium, Festuca, Poa, Anthoxanthum, Holcus, Agrostis and Alopecurus. Cross reactions are often observed between the allergens of Poaceae pollen and those of peas, beans, peanuts, kiwi, melons or strawberries (S ubiza, 2003; A bre u et al. 2008). Atmospheric conditions may have a great impact on the timing and abundance of grass pollen grains in the air (Emberlin et al. 1994, 2000; Norris-Hill, 1999; Sánchez-Mesa et al. 2003, 2005; C lary et al. 2004; Peternel et al. 2006; Smith and Emberlin, 2006; Stach et al. 2008; GarciaMozo, 2009).

The aim of the study was characterization of the grass pollen seasons and estimation of the effect of maximum and minimum temperature, relative air humidity, precipitation and maximum wind velocity on the concentration of the taxon's pollen.

\section{MATERIALS AND METHODS}

The measurement of grass (Poaceae) pollen fall was done by the gravimetric method with the use of 
a Durham sampler (D u rh a m, 1964). The sampler was placed in the western part of the city, in the Maria Curie-Skłodowska University Botanical Garden in Lublin $\left(51^{\circ} 16^{`} \mathrm{~N}, 22^{\circ} 30^{`} \mathrm{E}\right), 5$ metres above ground level (220 $\mathrm{m}$ AMSL). The pollen fall was expressed as the number of pollen grains per $1 \mathrm{~cm}^{-2}$ of slide surface, collected per day, in the years 2003, 2008 and per week (2001, 2002, 2004-2007).

On the basis of the results obtained, the date of the onset and end of the pollen season was determined as well as the length of season, the annual pollen count and the periods of their maximum concentrations. In order to analyse the influence of meteorological factors on the pollen season, daily values of five weather elements were taken into account: maximum and minimum temperature, relative air humidity, precipitation and maximum wind velocity noted from May to $\mathrm{Au}$ gust 2001-2008, as well as minimum temperature of January in 2001-2008. The data were obtained from the weather station of the UMCS Institute of Meteorology and Climatology situated $3 \mathrm{~km}$ from the measurement site.
Pearson's r correlation coefficients were calculated with the use of Statistica 7.1 StartSoft Inc. software to examine the correlations between the particular season features and weather conditions.

\section{RESULTS}

During eight years, the grass pollen season usually began in the first or second decade of May (Tab. 1). Maximum temperatures above $17^{\circ} \mathrm{C}$ from the 10 days that preceded flowering initiated the onset of pollen release, which is confirmed by the significant correlation coefficient $r=0.2560$. Ground frost in May delayed flowering, which is indicated by the high correlation coefficient $r=-0.9151$. In the years of study, the grass pollen season basically lasted till the end of August and exceptionally ended in the middle of the month in 2002 and 2008. The mean length of the pollen season was 107 days (Tab. 1).

Table 1

Results of the aerobiological study of grass pollen fall in Lublin in 2001-2008.

\begin{tabular}{|c|c|c|c|c|c|c|c|}
\hline \multirow{2}{*}{ Years } & \multicolumn{3}{|c|}{ Length of pollen season } & \multirow{2}{*}{$\begin{array}{c}\text { Annual } \\
\text { count } / \mathrm{cm}^{-2}\end{array}$} & \multicolumn{2}{|c|}{ Maximum pollen count } & \multirow{2}{*}{$\begin{array}{c}\% \text { of annua } \\
\text { count }\end{array}$} \\
\hline & onset & end & $\begin{array}{c}\text { duration } \\
\text { (days) }\end{array}$ & & grains $\times \mathrm{cm}^{-2} /$ day & week number & \\
\hline 2001 & 16.05 & 29.08 & 105 & 1767 & 48.7 and 48 & 21.27 & 2.7 \\
\hline 2002 & 1.05 & 14.08 & 106 & 1483 & 30.8 and 30 & 25.26 & 2.1 \\
\hline 2003 & 30.04 & 27.08 & 120 & 1538 & 39 & 26 & 2.5 \\
\hline 2004 & 12.05 & 25.08 & 105 & 741 & 18.4 & 28 & 2.5 \\
\hline 2005 & 23.05 & 31.08 & 100 & 992 & 33.7 and 32.8 & 26. 27 & 3.3 \\
\hline 2006 & 11.05 & 30.08 & 111 & 1196 & 39.3 & 27 & 3.3 \\
\hline 2007 & 9.05 & 29.08 & 112 & 1909 & 51.4 & 25 & 2.7 \\
\hline 2008 & 13.05 & 17.08 & 96 & 3615 & 176.8 & 27 & 4.9 \\
\hline
\end{tabular}

The highest annual counts, more than 3600 pollen grains $\times \mathrm{cm}^{-2}$, were observed in 2008; in the other years of study, the counts ranged from 741 to 1909 . A significant negative value of the correlation coefficient $r=-0.4729$ was obtained between the annual grass pollen count and the minimum temperature of January. The linear trend function was used for estimation of the tendency in the changes in the annual grass pollen counts (Fig. 1). The trend line indicates a remarkable increase in the annual counts.
The highest allergenic risk posed by grass pollen was noted in the $26^{\text {th }}$ and $27^{\text {th }}$ week (Tab. 1). The daily concentration reached 30 pollen grains $\times \mathrm{cm}^{-2} /$ day. The record concentration of Poaceae pollen reaching 176.8 grains $\times \mathrm{cm}^{-2} /$ day, which equalled almost $5 \%$ of the annual count, was reported in 2008. In the other seasons, the pollen concentration was 2-3 times lower. In 2004 grass pollen allergens posed the least risk. In the years of study, a very high grass pollen concentration persisted during 2 to 5 weeks each year (Tab. 2). 


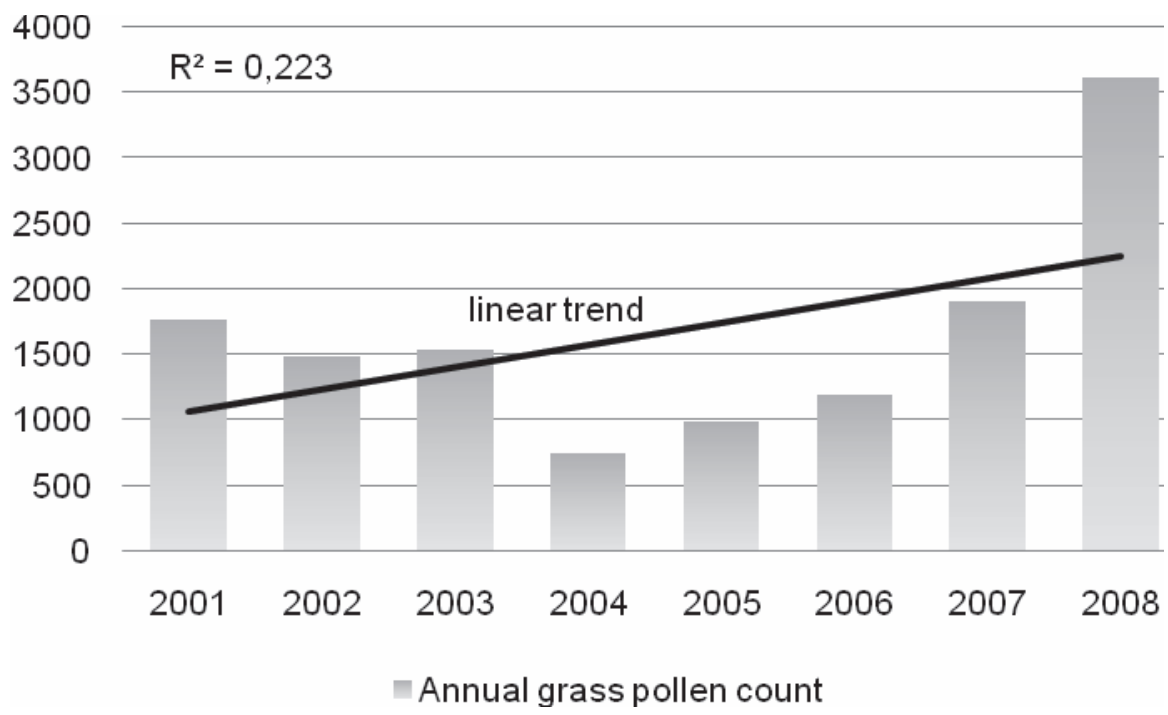

Fig. 1. Annual grass pollen counts in Lublin in 2001-2008.

Table 2

Number of weeks of each allergenicity rank (according to the CAN threshold system B el mo n te et al. 2000) for each investigated year in Lublin.

\begin{tabular}{|c|c|c|c|c|c|}
\hline \multirow[b]{2}{*}{ Years } & \multicolumn{5}{|c|}{ Number of weeks of each allergenicity rank } \\
\hline & $\begin{array}{c}\text { Null } \\
0.0 \\
\mathbf{0}\end{array}$ & $\begin{array}{c}\text { Low } \\
0.1-4.9 \\
\mathbf{1}\end{array}$ & $\begin{array}{c}\text { Mid } \\
5-19.9 \\
\mathbf{2}\end{array}$ & $\begin{array}{c}\text { High } \\
20-29.9 \\
\mathbf{3}\end{array}$ & $\begin{array}{c}\text { Very high } \\
>30 \\
\mathbf{4}\end{array}$ \\
\hline 2001 & 31 & 12 & 2 & 4 & 3 \\
\hline 2002 & 29 & 13 & 5 & 3 & 2 \\
\hline 2003 & 30 & 13 & 6 & 0 & 3 \\
\hline 2004 & 36 & 8 & 9 & 0 & 0 \\
\hline 2005 & 35 & 9 & 6 & 0 & 2 \\
\hline 2006 & 35 & 10 & 5 & 1 & 2 \\
\hline 2007 & 30 & 14 & 3 & 1 & 4 \\
\hline 2008 & 30 & 12 & 3 & 2 & 5 \\
\hline
\end{tabular}

The statistical analysis demonstrated a significant positive correlation between the grass pollen fall and maximum air temperature in five out of the eight study years (Tab. 3). The decrease in temperature in the seasons 2001 and 2002 was accompanied by a fall in the concentration of the taxon's pollen, which is indicated by significant correlation coefficients. In the years 2002, 2005 and 2006, a marked, statistically significant increase in pollen concentration was ob- served alongside a decrease in relative air humidity. Insufficient precipitation in the seasons of 2005 and 2006 increased the concentration of pollen grains in the air, which was confirmed by the statistic analysis. In the case of wind velocity, a statistically significant correlation was reported in 2005, 2006 and 2008. This confirms the observation that the stronger the wind, the higher concentration of grass pollen grains in the air. 
Table 3

Pearson's r correlation coefficients for the grass pollen fall and weather parameters (2001-2008).

\begin{tabular}{cccccc}
\hline Years & $\begin{array}{c}\text { Max. temp. } \\
\left(\mathrm{C}^{\circ}\right)\end{array}$ & $\begin{array}{c}\text { Min. temp. } \\
\left(\mathrm{C}^{\circ}\right)\end{array}$ & $\begin{array}{c}\text { Relative humidity } \\
(\%)\end{array}$ & $\begin{array}{c}\text { Precipitation } \\
(\mathrm{mm})\end{array}$ & $\begin{array}{c}\text { Max.wind } \\
(\mathrm{m} / \mathrm{s})\end{array}$ \\
\hline 2001 & $0.4339^{*}$ & $-0.4040^{*}$ & -0.0958 & -0.1572 & -0.1916 \\
2002 & $0.5286^{*}$ & $-0.2940^{*}$ & $-0.2990^{*}$ & 0.2687 & 0.1754 \\
2003 & 0.0898 & 0.0426 & -0.0434 & -0.1393 & 0.0740 \\
2004 & 0.1148 & 0.0136 & -0.1453 & -0.1095 & -0.1495 \\
2005 & 0.1894 & 0.1971 & $-0.4598^{*}$ & $-0.2957^{*}$ & $0.2668^{*}$ \\
2006 & $0.3034 *$ & 0.2210 & $-0.3893^{*}$ & $-0.4452^{*}$ & $0.3561^{*}$ \\
2007 & $0.2134 *$ & 0.1947 & -0.0960 & -0.0797 & -0.0712 \\
2008 & $0.3567^{*}$ & 0.1894 & -0.1822 & 0.0794 & $0.2640^{*}$ \\
\hline
\end{tabular}

* - a statistically significant correlation coefficient $(\mathrm{p}<0.05)$.

\section{DISCUSSION}

The grass pollen season in Lublin starts in the first or second half of May; similar results were obtained by authors of aerobiological studies in various regions of Poland (K a s p r z y k, 2002; P u c , 2002; Piotrowska and Weryszko-Chmielews$\mathrm{ka}, 2004$; Puc and Puc, 2004; Pi otrow ska, 2006; W e ry s z k o- C h mi e lew s k a (Ed.), 2006; Chłopek, 2007), England (Sánchez-M e s a et al. 2003; S mith and E m berlin, 2006), Denmark, Germany and Austria (E m b e r 1 i n et al. 2000). In the colder part of Europe - in Norway and Finland - grasses begin releasing pollen at the end of June and beginning of July (E m berlin et al. 2000), while in the south of Europe, e.g. in Spain, Portugal and Croatia, pollen release starts at the turn of March and April (Fernández-González, 1999; Peternel et al. 2005, 2006; A breu et al. 2008; GarcíaMozo et al. 2009).

In their phenological observations of grass pollen release in various European regions, E m b e r li n et al. (1994, 2000), Sán c hez - M e s a et al. (2005), Smith and E m berlin (2006) as well as S t a c h et al. (2008) reported a significant effect of temperature on the onset of Poaceae flowering. Similar observations were reported in Lublin in the years 2001-2008.

In Poland and other European countries, grasses end flowering on the last days of August ( $F$ e r $n$ á $n$ dez-González, 1999; K a s przyk, 2002; Piotrowska and Weryszko-Chmielews$\mathrm{ka}, 2004$; Puc and Puc, 2004; Peternel et al. 2005, 2006; Pi o trow s ka, 2006; Wery s z-
ko-Chmielewska (Ed.), 2006; Abreu et al. 2008).

Long-term aeropalynological research conducted worldwide is an attempt to establish trends in macroregional changes in grass pollen concentration. While analyzing their results obtained from numerous seasons, Fernánd e z-G o nzále z (1999) and Sán c he z - M e s a et al. (2003) observed slight trends towards an increased Poaceae concentration. An increase in the annual counts was also reported in $\mathrm{Lu}-$ blin during the eight study years.

The highest risk posed by grass pollen allergens was reported in Lublin at the end of June and beginning of July, i.e., in the $26^{\text {th }}$ and $27^{\text {th }}$ weeks. Similar results were presented by $\mathrm{S}$ á $\mathrm{n} \mathrm{che} \mathrm{z}-\mathrm{M}$ e s a et al. (2003) in their study in England. In Spain and Croatia, high grass pollen content at the end of May, i.e. in the $22^{\text {nd }}$ week, was noted by F e r n án d e z - G o n z ále z (1999), Sánchez-M e s a etal. (2003), La torre and B elmonte (2004), Peternel et al. (2005, 2006), A breu et al. (2008), and García-Mozo et al. (2009).

The results obtained by Peternel et al. (2006) from Zagreb, Latorre and Belmonte (2004) from Catalonia as well as by S $\mathrm{mi}$ th and $\mathrm{E} \mathrm{m}$ b e r li n (2006) from London demonstrate that a very high concentration of grass pollen allergens (over 30 pollen grains $\times \mathrm{m}^{-3} /$ day) persists from 4 to 5 weeks. In Lublin, such concentration persisted over 2.5 weeks.

The grass pollen concentration in the air in Lublin was positively and significantly correlated with maximum air temperature and maximum wind velocity. A similar correlation was observed by $\mathrm{Norris}$ - 
Hill (1999), Puc (2002), Sánchez-Mesa et al. (2003, 2005), Pu c and Puc (2004), P e ternel et al. (2006), Smith and Emberlin (2006), and $\mathrm{Stach}$ et al. (2008). An increase in the grass pollen concentration accompanying a fall in relative air humidity and precipitation was noted by, among others, S á n c he z - M e s a et al. (2003, 2005), P u c and Puc (2004), and Peternel et al. (2006).

\section{CONCLUSIONS}

1. The differences in grass pollen release in the area of Lublin in the years 2001-2008 related to the dates of appearance of pollen grains in the air, length of pollen seasons, annual pollen count and maximum pollen concentrations.

2. The onset of the grass pollen season was dependent on maximum and minimum temperatures.

3. The trend line indicates a marked increase in the annual counts of grass pollen grains in the course of the seasons.

4. The maximum grass pollen concentration, i.e., over 30 grains $\times \mathrm{cm}^{-2} /$ day, was observed in the $26^{\text {th }}$ and $27^{\text {th }}$ weeks.

5. The grass pollen concentration in the air displays a statistically significant correlation with maximum and minimum air temperatures, relative air humidity, precipitation and maximum wind velocity.

\section{REFERENCES}

Aboulaich N., Bouziane H., Kadiri M., del Mar Trigo M., Riadi H., Kazzaz M., Merzouki A., 2009. Pollen production in anemophilous species of the Poaceae family in Tetouan (NW Morocco). Aerobiologia, 25: 27-38.

Abreu I., Ribeiro N., Ribeiro H., Oliveira M., Cruz A., 2008. Airborne Poaceae pollen in Porto (Portugal) and allergenic profiles of several grass pollen types. Aerobiologia, 24: 133-140.

Belmonte J., Canela M., Guardia R. A., 2000. Comparison between categorical pollen data obtained by Hirst and Cour sampling methods. Aerobiologia, 16: 177-185.

Chłopek K., 2007. Grass pollen (Poaceae) in the air of Sosnowiec (Poland), 1997-2006. Acta Agrobot. 60 (2): $79-$ 86.

Clary J., Savé R., Biel C., de Herralde F., 2004. Water relations in competitive interactions of Mediterranean grasses and shrubs. Ann. Appl. Biol. 144 (2): 149-155.

Clay t on W. D., 1993. Gramineae. In: Heywood V. H. (Ed.): Flowering Plants of the World. Oxford University Press, New York.

D u rh a m O. C., 1964. Proposed standard method of gravity sampling. J. Allergy, 17: 79.
Emberlin J., Jaeger S., Dominguez-Vilches E., Soldevilla C. G., Hodal L., Mandrioli P., Lehtimäki A. R., Savage M., Spieksma F. Th., B artlett C., 2000. Temporal and geographical variations in grass pollen seasons in areas of western Europe: an analysis of season dates at sites of the European pollen information system. Aerobiologia, 16: 373-379.

Emberlin J., Jones S., Bailey J., Caulton E., Corden J., Dubbels S., Evans J., Mc Donagh N., Millington W., Mullins J., Russel R., Spencer T., 1994. Variation in the start of the grass pollen season at selected sites in the United Kingdom 1987-1992. Grana, 33: 94-99.

Fernández-González D., Valencia-Barrera R. M., Vega A., Díaz de la Guardia C., Trigo M. M., Carińanos P., Guŕrdia A., Pertińez C., Rodríguez Rajo F. J., 1999. Analysis of grass pollen concentrations in the atmosphere of several Spanish sites. Polen, 10:123-132.

Frey L., 2000. Trawy niezwyciężone (wybrane zagadnienia z historii, taksonomii i biologii Poaceae). / Invincible grasses (chosen issues of the history, taxonomy and biology of Poaceae). Łąkarstwo w Polsce, 3: 9-20.

García-Mozo H., Galán C., Belmonte J., Bermejo D., Candau P., Díaz de la Guardia C., Elvira B., Gutiérrez M., Jato V., Silva I., Trigo M. M., Valencia R., Chuine I., 2009. Predicting the start and peak dates of the Poaceae pollen season in Spain using process-based models. Agricultural and Forest Meteorology, 149: 256-262.

Kasprzyk I., 2002. Ziarna pyłku traw w powietrzu Rzeszowa i okolic. / Airborne grass pollen in the atmosphere of Rzeszów and neighbourhood. Ann. Univ. Mariae CurieSkłodowska, Sect. Hortic. EEE, 10: 123-129.

Latorre F., Belmonte J., 2004. Temporal and spatial distribution of atmospheric Poaceae pollen in Catalonia (NE Spain) in 1996-2001. Grana, 43: 156-163.

Mizianty M., 1995. Trawy - grupa roślin, która odniosła ewolucyjny sukces. / Grasses - a plant group that achieved an evolutionary success. Wiad. Bot. 39 (1-2): 59-70.

Niczy por u k A., 2000. Ekosystemy trawiaste w kształtowaniu i ochronie środowiska. Wydawnictwo Politechniki Białostockiej.

Nor ris - Hill J., 1999. The diurnal variation of Poaceae pollen concentrations in a rural area. Grana, 38: 301-305.

Obtułowicz K., Szczepanek K., Szczeklik A., 1990. The value of pollen count for diagnosis and therapy of pollen allergy in Poland. Grana, 29: 318-320.

Peternel R., Hrga I., Hercog P., Čulig J., 2005. Poaceae pollen concentrations in the atmosphere of three inland Croatian sites (2003-2004). Coll. Antropol. 29 (2): 671-676.

Peternel R., Srnec L., Čulig J., Hrga I., Hercog P., 2006. Poaceae pollen in the atmosphere of Zagreb (Croatia), 2002-2005. Grana, 45: 130-136.

Pi otrowska K., 1999. Biologia kwitnienia i opad pyłkowy żyta (Secale cereale L.). / Biology of flowering and pol- 
len fall of rye (Secale cereale L.). Bibl. Fragm. Agron. 6: 203-208.

Piotrowska K., 2006. The effect of meteorological factors on the start of the grass pollen season in Lublin in the years 2001-2004. Acta Agrobot. 59 (1): 365-372.

Piotrowska K., Weryszko-Chmielewska E., 2004. Analysis of grass pollen concentration in aeroplankton of Lublin, Poland. J. Agrobiol. Ecol. 1: 148-154.

Prieto-Baena J. C., Hidalgo P. J., Domínguez E., Galín C., 2003. Pollen production in the Poaceae family. Grana, 42: 153-160.

Pu c M., 2002. Porównanie zawartości pyłku traw (Poaceae) w aeroplanktonie Szczecina w latach 2000-2001. / Comparison of grass (Poaceae) concentration in aeroplankton of Szczecin in 2000 and 2001. Ann. Univ. Mariae Curie-Skłodowska, Sect. Hortic. EEE, 10: 131-137.

Puc M., Puc, M. I., 2004. Allergenic airborne grass pollen in Szczecin, Poland. Ann. Agric. Environ. Med. 11 (2): 237-244.

Rog a ls k i M., 2004. Łąkarstwo. Wydawnictwo Kurpisz, Poznań.

Rut kow ski L., 1998. Klucz do oznaczania roślin naczyniowych Polski niżowej. Wydawnictwo Naukowe PWN, Warszawa.

Sánchez-Mesa J. A., Galán C., Hervás C., 2005. The use of discriminant analysis and neural networks to forecast the severity of the Poaceae pollen season in a region with a typical Mediterranean climate. Int. J. Biometeorol. 49 (6): 355-362.

Sánchez-Mesa J. A., Smith M., Emberlin J., A1litt U., Caulton E., Galan C., 2003. Characteristics of grass pollen seasons in areas of southern Spain and the United Kingdom. Aerobiologia, 19: 243-250.

Smith M., Emberlin J., 2006. A 30-day-ahead forecast model for grass pollen in north London, United Kingdom. Int. J. Biometeorol 50: 233-242.

S pieks ma F. Th. M., 1989. Airborne pollen concentrations in the European Economic Community (EEC). VI. Poaceae (Grasses) 1982-1986. Aerobiologia, 5: 38-43.

Stach A., Smith M., Prieto-Baena J. C., Emberlin J., 2008. Long-term and short-term forecast models for Poaceae (grass) pollen in Poznań, Poland, constructed using regression analysis. Environ. Exp. Bot. 62: 323-332.

Subiza J., 2003. Gramíneas: Aerobiología y polinosis en Espańa. Alergol. Inmunol. Clin. 18 (3): 7-23.

Tut in T. G. (Ed.), 1980. Graminales. In: Flora Europaea. 5. Cambridge Univ. Press, Cambridge: 118-267.

Weryszko-Chmielewska E. (Ed.), 2006. Pyłek roślin w aeroplanktonie różnych regionów Polski. / Plant pollen in aeroplankton of different regions of Poland. Katedra i Zakład Farmakognozji AM w Lublinie: 13-115.
Weryszko-Chmielewska E., Piotrowska K., 2006. Cechy ekologiczne kwiatów roślin wiatropylnych. [In]: E. Weryszko-Chmielewska (ed.), Pyłek roślin w aeroplanktonie różnych regionów Polski: 171-175, Katedra i Zakład Farmakognozji AM, Lublin (in Polish).

\section{Analiza sezonów pyłkowych traw (Poaceae) w Lublinie w latach 2001-2008}

\section{Streszczenie}

Alergeny pyłku traw są częstą przyczyną alergii pyłkowej w Polsce oraz innych krajach Europy. Prowadzone w Lublinie od 2001 roku badania aeroplanktonu posłużyły do scharakteryzowania przebiegu sezonów pyłkowych traw oraz oceny wpływów temperatury maksymalnej i minimalnej, wilgotności względnej powietrza, opadów i maksymalnej prędkości wiatru na koncentrację pyłku tego taksonu. Badania przeprowadzono metodą grawimetryczną. W ciągu ośmiu lat badań, sezon pyłkowy traw rozpoczynał się zwykle w pierwszej lub drugiej dekadzie maja i trwał z reguły do końca sierpnia, wyjątkowo w 2002 i 2008 roku do połowy sierpnia. Średnia długość sezonu pyłkowego wynosiła 107 dni. Największe zagrożenie alergenami pyłku tego taksonu zarejestrowano w 26 i 27 tygodniu. Najwyższe sumy roczne zanotowano w 2008 roku, ponad 3600 ziaren pyłku $\times \mathrm{cm}^{-2}$, natomiast w pozostałych latach badań sumy zawierały się pomiędzy 741 a 1909. Termin początku sezonu pyłkowego i jego przebieg w znacznej mierze zależały od warunków pogodowych, co potwierdziły wyniki analizy statystycznej. Największy istotny wpływ na sezon pyłkowy wywierała temperatura maksymalna, wilgotność względna powietrza oraz maksymalna prędkość wiatru. 